\title{
Evaluation of an active and early surveillance methodology for visceral leishmaniasis by molecular detection in road-killed wild fauna
}

\author{
Avaliação de metodologia de vigilância ativa e precoce da leishmaniose \\ visceral por detecção molecular em fauna silvestre atropelada
}

Eloiza Teles Caldart* (1); Fernanda Pinto-Ferreira1; Andressa Maria Rorato Nascimento de Matos; Aline Ticiani Pereira Pascoal'; Amanda Bertão-Santos ${ }^{1}$; Regina Mitsuka-Breganó; ; Italmar Teodorico Navarro

' Departamento de Medicina Veterinária Preventiva, Universidade Estadual de Londrina - UEL, Londrina, PR, Brasil

How to cite: Caldart ET, Pinto-Ferreira F, Matos AMRN, Pascoal ATP, Bertão-Santos A, Mitsuka-Breganó R, et al. Evaluation of an active and early surveillance methodology for visceral leishmaniasis by molecular detection in road-killed wild fauna. Braz J Vet Parasito/ 2021; 30(2): e027920. https://doi.org/10.1590/S1984-29612021026

\begin{abstract}
The present study aimed to evaluate a methodology for active surveillance of visceral leishmaniasis by detecting Leishmania DNA in organs of wild road-killed animals from November 2016 to October 2018 in the North of Paraná, Brazil. The collection points of road-killed wild animals were georeferenced. The animals were autopsied and samples of bone marrow, lymph node, liver, spleen, and ear skin were collected. Genomic DNA was extracted and subjected to PCR for amplification of Leishmania spp. 18S, kinetoplastic DNA (kDNA), HSP70, and ITS1 genes, and DNA sequencing was performed. The primers used for the amplification of kDNA, ITS1, and HSP70 genes presented non-specific results. Of the 66 mammals collected from 24 different municipalities, one Southern Tamandua (Tamandua tetradactyla) presented DNA of Leishmania spp. in lymph nodes by 18S PCR. DNA sequencing confirmed the results of the subgenus, Viannia, identification. We suggest using the methodology showed in the present study in the active and early surveillance of visceral leishmaniasis in a non-endemic area.
\end{abstract}

Keywords: One Health, prevention, molecular detection.

\begin{abstract}
Resumo
O objetivo do presente estudo foi avaliar uma metodologia de vigilância ativa da leishmaniose visceral por meio da detecção de DNA de Leishmania em órgãos de animais silvestres atropelados, de novembro de 2016 a outubro de 2018, no Norte do Paraná, Brasil. Os pontos de coleta dos animais silvestres atropelados foram georreferenciados. Os animais foram autopsiados e amostras de medula óssea, linfonodo, fígado, baço, e pele de orelha foram coletados. DNA genômico foi extraído e submetido à PCR para amplificação de quatro diferentes regiões de Leishmania spp.: 18S, kDNA, HSP70 e ITS1, sequenciamento de DNA foi realizado. Os iniciadores utilizados para a amplificação dos genes kDNA, ITS1 e HSP70 apresentaram resultados inespecíficos. Dos 66 mamíferos coletados em 24 diferentes municípios, um tamanduá-mirim (Tamandua tetradactyla) apresentou DNA de Leishmania spp. em linfonodo na PCR, que amplificou o gene 18S. O sequenciamento de DNA confirmou o resultado e demonstrou a presença do subgênero Viannia. Sugere-se o uso da metodologia apresentada no presente estudo na vigilância ativa e precoce da leishmaniose visceral em área não endêmica.
\end{abstract}

Palavras-chave: Saúde Única, prevenção, detecção molecular. 


\section{Introduction}

Parasites of the genus, Leishmania (Kinetoplastida: Trypanosomatidae), are protozoans that infect numerous species of mammals (Gramiccia, 2011). Infections by the aforementioned parasite might lead to vector diseases with a broad spectrum of clinical signs; these are collectively known as leishmaniasis, which are neglected infectious diseases (Dujardin et al., 2008) which cause 20,000 to 40,000 deaths per year (Alvar et al., 2012), The circumstances surrounding transmission of leishmaniasis are continually changing in relation to environmental, demographic, and human behavioral factors, which lead to changes in the reach and density of hosts, vectors and reservoirs, increasing human and animal exposure to infected sandflies (Roque \& Jansen, 2014).

A notable geographical expansion of visceral leishmaniasis has occurred in the Southern region of Brazil in recent years. In the state of Paraná, the vector, Lutzomyia longipalpis, was first identified in 2012 in the Foz do Iguaçu (Santos et al., 2012), Western region of the state. The autochthonous canine cases in 2012 demonstrated the rapid expansion of the agent (Dias et al., 2019), and the first reported human case occurred in 2014 (SINAN, 2020; Trench et al., 2016). Despite the efforts of the municipal and state health agencies, it was not possible to contain vector propagation and agent dispersion between dogs and humans, causing five deaths from 2014 to 2018 (SINAN, 2020). Despite this, the Northern region of the state of Paraná is considered indene for visceral leishmaniasis; however, findings in synanthropic rodents and dogs have indicated that the agent is circulating in the region (Caldart et al., 2017, 2018). The most intriguing is the absence of the vector in this region of the state (Neitzke-Abreu et al., 2012; Silva et al., 2013; Silva et al., 2008; Reinhold-Castro et al., 2013). Canine visceral leishmaniasis spread quickly in cities West of São Paulo state, being the most feasible route to be covered by the disease towards the Northern border of the state of Paraná (D'Andrea et al., 2015).

Animal species that harbor a given etiological agent, from an epidemiological point of view, can be classified as hosts, reservoirs or sentinels. The hosts host these organisms, without having great epidemiological importance. Reservoirs are defined as responsible for maintaining the etiological agent in nature, in the case of leishmaniasis in the wild, a complex of species is observed acting as reservoirs and these species vary greatly according to space-time conditions. Therefore, reservoirs need to present some characteristics such as: competence for transmissibility, maintenance of infection, with or without symptoms (Roque \& Jansen, 2014). Sentinel animals are useful as early warning signs of imminent danger to humans because they must be able to develop an adequate and detectable response to a pathogen (McCluskey et al., 2006). Various scientific studies have demonstrated that wild animals might serve as important sentinels of the wild cycle of leishmaniasis, especially in places where it has not yet been effectively established in the urban cycle (Roque \& Jansen, 2014). PCR might be a useful tool for the detection of these sentinels because it allows for a massive specific amplification of Leishmania DNA and is applicable directly to clinical samples without the need for parasite isolation (Van der Auwera \& Dujardin, 2015). The present study aimed to evaluate the methodology of active and early surveillance of visceral leishmaniasis by detecting Leishmania spp. DNA in organs of road-killed wild animals from November 2016 to October 2018 in municipalities in the North of Paraná.

\section{Material and Methods}

\section{Ethics approval}

The project was approved by the Ethics Committee on Animal Use of the State University of Londrina in October 2017 under number 30/2017 and was approved by the System of Authorization and Information on Biodiversity (SISBIO) on October 2016 under number 55384-1.

\section{Study area}

The state of Paraná is divided into 22 health regions (HR), and the municipalities participating in the study were those attended by the $15^{\text {th }}, 16^{\text {th }}, 17^{\text {th }}$, and $18^{\text {th }}$ HR (Figure 1).

\section{Collecting road-killed animals}

The project team traveled to four specific transects (Figure 1), one each week, and the road-killed wild animals found from November 2016 to October 2018 were collected. The point of departure and arrival of the transects 


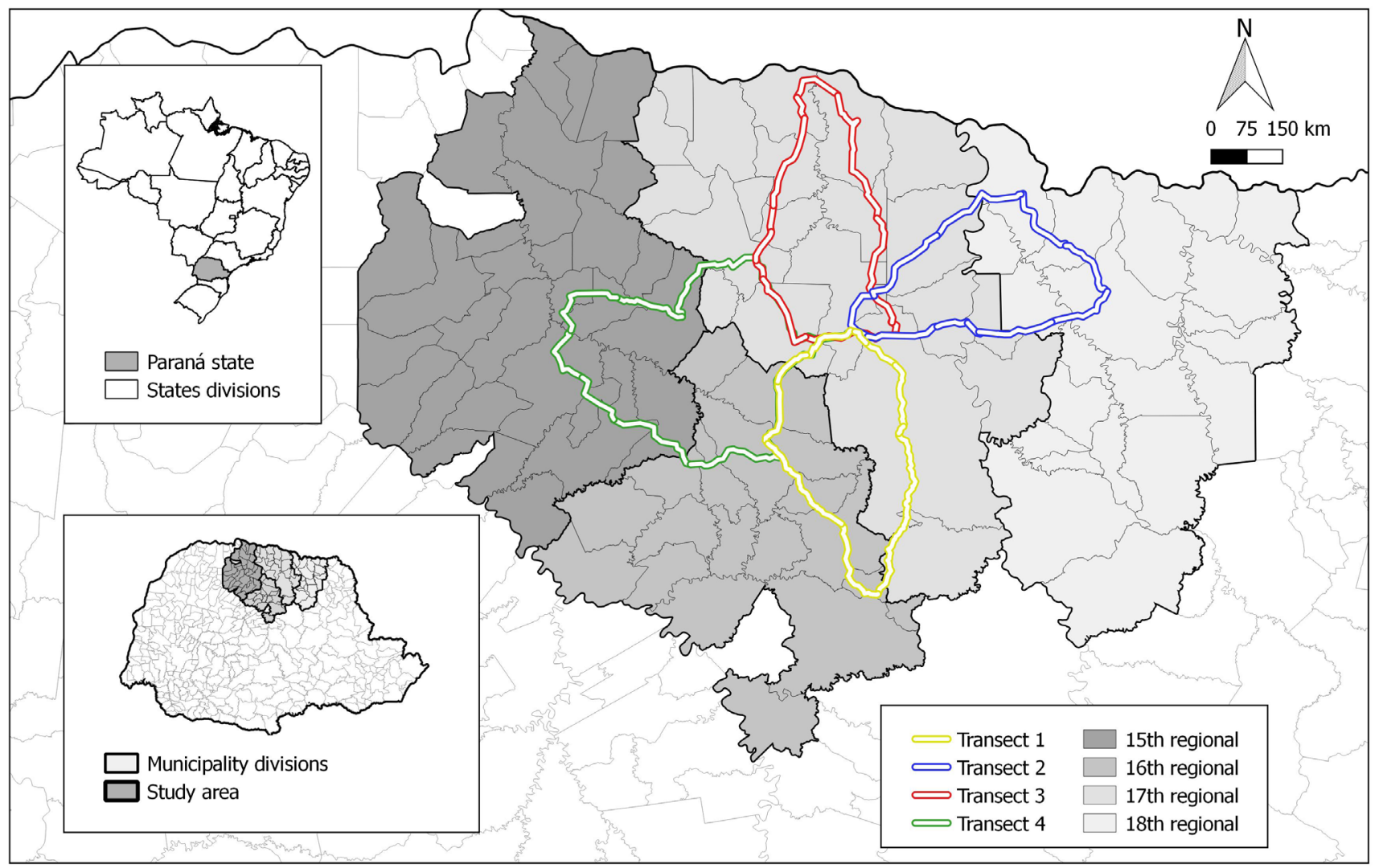

Figure 1. Map of the North of Paraná with emphasis on the municipalities and health regionals participating in the research, and on the transects traveled weekly in the active search of wild animals road-killed from November 2016 to October 2018.

was always Londrina $\left(-23.2927^{\circ},-51.173223^{\circ}\right)$. The average speed was 40 to $60 \mathrm{~km} / \mathrm{h}$, three people were always in the car, the driver and two researchers, one watching the right side and the other the left side of the highway. Opportunistic collections were also made through communication of the trampling by the $2^{\text {nd }}$ Company of Environmental Police or $2^{\text {nd }}$ Road Police Company. The animals were collected dead and was used only carcasses with fresh condition of conservation (less than 24h after death) (Pugliares et al., 2007), without evisceration, absence of fly larvae. Carcasses were placed in bags for biological material, transported to the Laboratory of Animal Pathology, Universidade Estadual de Londrina, and kept in a cold room $\left(-4^{\circ} \mathrm{C}\right)$ until the autopsy (varying three to 12 hours). At autopsy, the species were identified and organs fragments were collected to molecular analysis.

\section{Georeferencing}

All the trampling points of the study were mapped using the global positioning system (GPS) with the mobile app My GPS Coodinators with with an accuracy of 3 meters. The coordinate reference system used was EPSG:31981, spatial analysis of the occurrence was performed with QGIS, version 2.14.1, using the kernel intensity estimator.

\section{DNA extraction and PCR}

DNA extraction from bone marrow, lymph nodes (pool of popliteal and/or submandibular and/or prescapular and/or inguinal nodes), spleen, liver, and ear tip skin was performed with the commercial PureLink Genomic DNA Mini Kit (Thermo Fisher Scientific, Waltham, USA) according to the manufacturer's recommendations. A negative control (ultrapure water) was added to each extraction set. The extracted material was aliquoted into 1.5-ml sterile polypropylene tubes, identified, and stored at $-20^{\circ} \mathrm{C}$ for use in the PCR. The quantification of extrated DNA was performed using L-QUANT (Loccus Biotechnology, Cotia, São Paulo, Brazil). The samples with extracts had less than a minimum concentration of $30 \mathrm{ng} / \mu \mathrm{L}$ were subjected to extraction again. Those that did not present the minimum quantity in the second extraction were excluded from the study and considered degraded. 
For the amplification of DNA of parasites of the Leishmania genus, four different PCR protocols were tested seeking to determine the best. The first protocol was a nested PCR (nPCR) with a target fragment of the smaller ribosomal subunit (18S), a highly conserved region among Leishmania species. In this nPCR, the outer primers were R221- and R332-amplifying parasites of the order, Kinetoplastida. The resulting amplification of the first reaction was used as a sample for the second reaction, and the primers used in the second reaction were R222 and R333 resulting in fragment of $353 \mathrm{bp}$ (Van Eys et al., 1992). The annealing temperature used were $55^{\circ} \mathrm{C}$ in the first reaction and $60^{\circ} \mathrm{C}$ in the second.. The second protocol tested was a heminested-PCR (hnPCR), which amplifies the minicircle of kinetoplastic DNA (kDNA), which, according to Aransay et al. (2000), is an ideal target as it is present in 10,000 copies per Leishmania cell. The first reaction was performed with the primers, LinR4 and LinR17, and the second with LinR4 and LinR19, generating a fragment of $720 \mathrm{bp}$. The annealing temperature used were $50^{\circ} \mathrm{C}$ in the first reaction and $55^{\circ} \mathrm{C}$ in the second.. To avoid inhibition in the second reaction of nPCR or hnPCR due to a possible large amount of DNA, the second reaction was performed twice, once without diluting the result of the first reaction and once diluting the result of the first reaction in a 1:4 ratio.

The third protocol used applied as a simple PCR that amplifies the gene ITS1 of the genus Leishmania, which is more polymorphic, allowing for better discrimination of the different species through DNA sequencing. In particular, the LIT.SR and L5.8S primers were used (Schönian et al., 2003) amplifying a fragment of 300-350 bp depending on the species; with an annealing temperature of $57^{\circ} \mathrm{C}$. The fourth protocol is a simple PCR, but now targets heat shock protein 70 (HSP70) gene, which is extensively used for Leishmania species typing (Silva et al., 2010). The primers, IRD and IRM, described by (Requena et al., 2012) were employed, resulting in an amplification of a fragment of 516-733bp depending on the subgenus. The annealing temperature adopted were $60^{\circ} \mathrm{C}$.

The conditions of the reactions were denaturation at $94^{\circ} \mathrm{C}$ for $5 \mathrm{~min}$, followed by cycles of $30 \mathrm{~s}$ to $94^{\circ} \mathrm{C}, 30 \mathrm{~s}$ for the annealing temperature, $30 \mathrm{~s}$ to $72^{\circ} \mathrm{C}$ for extension, and a final extension at $72^{\circ} \mathrm{C}$ for $5 \mathrm{~min}$. For the amplifications, Platinum ${ }^{\circledR T}$ Taq DNA Polymerase (Life Technologies, Carlsbad, USA) was used. The four PCR protocols employed had analytical sensitivity for one parasite. All the reaction sets included a negative control (ultrapure water) and a positive control with a Leishmania species that does not occur in Brazil [Leishmania (Leishmania) tropica IOCL0571 or L. (L.) major IOCL0581] to avoid any suspicion of contamination. The amplified products generated in the PCR reactions were visualized with 1.5\% agarose gel electrophoresis (Invitrogen ${ }^{\circledR}$, Carlsbad, California, USA) stained with syBr safe DNA stain (Invitrogen $\left.{ }^{\circledR}\right)$ in a horizontal vat with TEB 1X solution pH 8.4 (89 mM Tris, $89 \mathrm{mM}$ boric acid, $6 \mathrm{mM}$ EDTA) as the running conducting fluid. The gel was visualized under ultraviolet (UV) light using Loccus biotechnology software (Loccus Biotechnology, Cotia, SP, BRA) to yield the images. To avoid errors due to non-specific amplification, only samples with DNA sequencing confirmation were considered positive in the present study.

\section{DNA sequencing by sanger}

PCR products were purified with PureLink Gel Extraction Kit (Invitrogen, Molecular Probes, Eugene, USA) and quantitated using L-QUANT. Direct sequencing was performed using BigDye Terminator v.3.1 Cycle Sequencing kit (Applied Biosystems, Carlsbad, USA) on a 3500 Genetic Analyzer (Applied Biosystems, Carlsbad, USA) according to the manufacturer's instructions. The sequences obtained were examined for quality using PHRED software. Consensus sequences were determined by CAP3 software and sequence identity was determined by comparison with all sequences deposited on GenBank using BLAST software. Other analyses were carried out using BioEdit and Chromas software.

\section{Phylogenetic reconstruction}

The phylogenetic relationships between Leishmania sequence detected in the present study (Leishmania Viannia PR-TT15) and GenBank standard sequences were characterized by the alignment of 257 nucleotides of the minor subunit (18S) of ribosomal RNA using the maximum likelihood method with 1000 bootstraps, using Tamura-Nei evolution model in the MEGA 10.2.4 software. The tree was rooted with Trypanosoma cruzi and the GenBank sequences used in this tree from Viannia subgenus were: OKGQ332355, OKGQ332358, and OKJN003595 and from the Leishmania subgenus were: OKEU825208, OKFJ263545, OKFJ263546, and OKGQ332354.

\section{Results}

In the study period, 66 mammals were collected from 24 different municipalities, and there was a greater concentration of animals collected in Londrina, Mauá da Serra, Tamarana, and Faxinal (Figure 2). Regarding the 


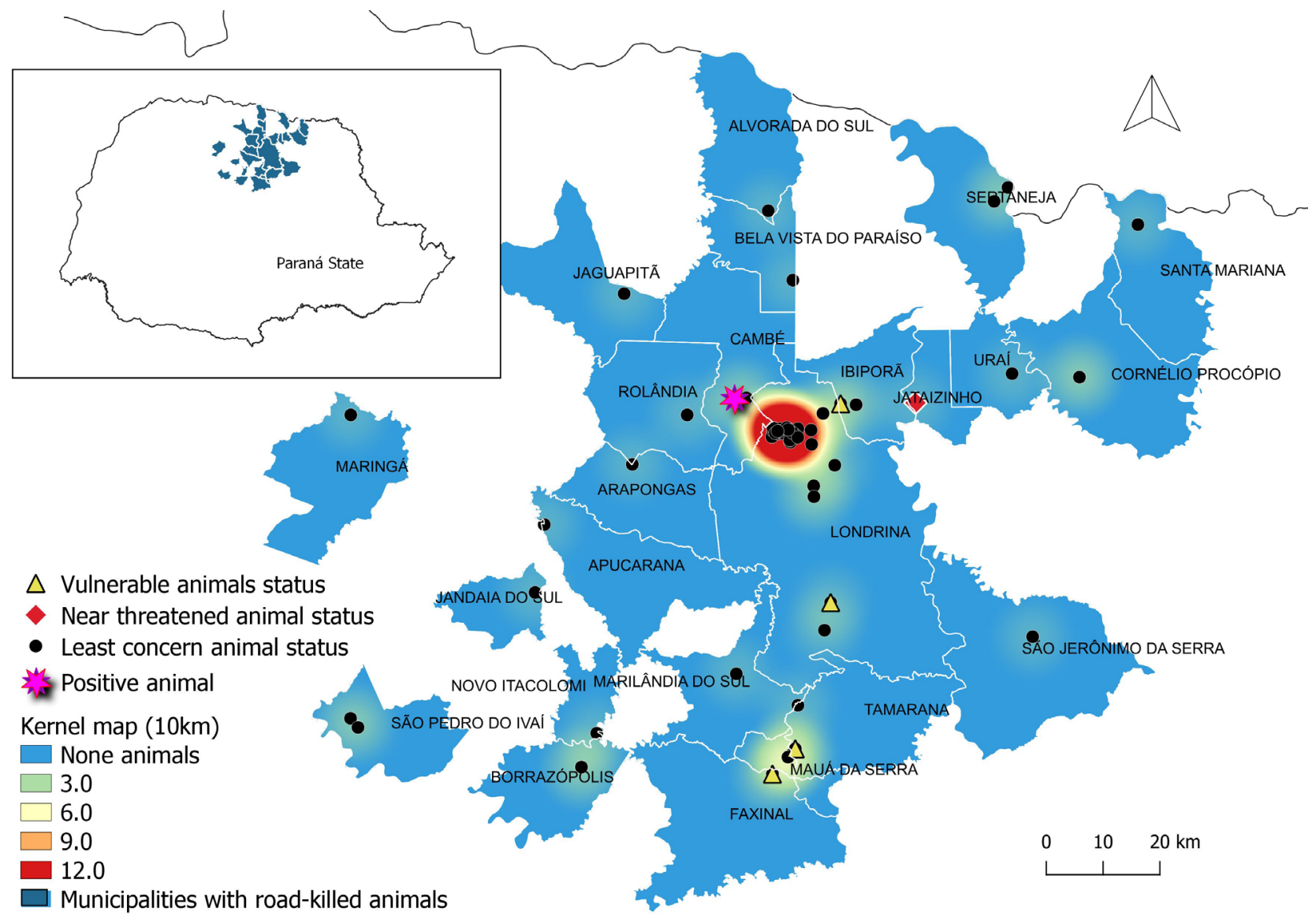

Figure 2. Kernel map demonstrating the concentration and the conservation status of road-killed wild animals collected in 24 municipalities belonging to the 15th, 16th, 17th and 18th regional health centers of the state of Paraná from November 2016 to October 2018.

transects, 15 animals were collected in T1 in ten travels, nine in T2 in 12 travels, four in T3 in nine travels, and none in T4 in ten travels, and 57.6\% (38/66) were collected outside transects. The most collected animal species was Didelphis albiventris, representing $37.9 \%$ of the total (25/66). On the other hand, we highlight the large number of carnivores $(30.3 \%, 20 / 66)$ represented by eight species (Table 1). Among them, Leopardus wiedii was observed, which is considered almost threatened by the International Union for the Conservation of Nature and Natural Resources (IUCN, 2019), as well as Leopardus guttulus, already among the endangered and classified species as vulnerable by IUCN (Figure 2). Of the total number of animals, $59.1 \%$ were male, $61.3 \%$ were adults, $35.5 \%$ were young, and $3.3 \%$ were puppies.

With regard to DNA extraction, we yielded a success rate of $98.5 \%(65 / 66)$ for the liver, $96.8 \%(61 / 63)$ for ear tip skin, 78.3\% (47/60) for bone marrow, 76.8\% (43/56) for the lymph node, and 70.8\% (46/65) for the spleen. Differences in the number of samples subjected to DNA extraction were based on the availability of the organ in the animal, as some organs were not found due to the degree of destruction (for example, complete organ rupture). In addition, degree of autolysis in some cases was observed due to the color, consistency, and odor alterations of organs, mainly in the carcasses with intestinal rupture or trampling that occurring on hot and humid days.

The PCR results from the ITS1 and kDNA genera presented non-specific bands in the electrophoresis gel, primarily those that did not correspond to the target size; however, some at similar sizes did not correspond, either, which were sent for DNA sequencing without success, presenting non-specific amplification (data not shown). The PCR of the HSP70 gene was positive in several organs of Hydrochoerus hydrochaeris and Cavia aperea, both from the Rodentia order - but we again did not have success in sequencing. One lymph node sample from a T. tetradactyla (Southern Tamandua) was positive with 18S PCR, and sequencing (Supplementary File 1) confirmed the presence of Leishmania DNA from the Viannia subgenus (Figure 3). 
Table 1. Scientific and popular name, frequency and transect of collection of the road-killed wild animals collected in municipalities in the North of Paraná from November 2016 to October 2018.

\begin{tabular}{|c|c|c|c|}
\hline Scientific name & Popular name & Frequency of collection & Transect \\
\hline Didelphis albiventris & White-eared Possum & $37.9 \%(25 / 66)$ & 2-T1, 3-T2, 20-oot ${ }^{1}$ \\
\hline Cerdocyon thous & Crab-eating Fox & $7.6 \%(5 / 66)$ & 3-T1, 1-T2, 1-oot \\
\hline Nasua nasua & South American Coati & $7.6 \%(5 / 66)$ & 2-T1, 1-T3, 2-oot \\
\hline Leopardus guttulus & Southern Tiger Cat & $6.1 \%(4 / 66)$ & 3-T1, 1-T2 \\
\hline Sapajus apella & Margarita Island Capuchin & $6.1 \%(4 / 66)$ & 4-oot \\
\hline Tamandua tetradactyla & Southern Tamandua & $6.1 \%(4 / 66)$ & 1-T1, 1-T2, 2-oot \\
\hline Dasypus novemcinctus & Nine-banded armadillo & $6.1 \%(4 / 66)$ & 1-T1, 1-T2, 2-oot \\
\hline Cavia aperea & Brazilian Guinea Pig & $4.5 \%(3 / 66)$ & 1-T3, 2-oot \\
\hline Hydrochoerus hydrochaeris & Capybara & $3.0 \%(2 / 66)$ & 1-T2,1-oot \\
\hline Puma concolor & Puma & $3.0 \%(2 / 66)$ & 1-T1, 1-oot \\
\hline Coendou spinosus & Hairy Dwarf Porcupine & $3.0 \%(2 / 66)$ & 1-oot \\
\hline Galictis cuja & Lesser Grison & $1.5 \%(1 / 66)$ & 1-T1 \\
\hline Leopardus wiedii & Margay & $1.5 \%(1 / 66)$ & $1-\mathrm{T} 2$ \\
\hline Leopardus pardalis & Ocelot & $1.5 \%(1 / 66)$ & $1-\mathrm{T3}$ \\
\hline Lepus europeus & Hare & $1.5 \%(1 / 66)$ & 1-oot \\
\hline Procyon cancrivorus & Crab-eating Raccoon & $1.5 \%(1 / 66)$ & $1-\mathrm{T} 1$ \\
\hline Mazama gouazoubira & Gray Brocket & $1.5 \%(1 / 66)$ & $1-\mathrm{T} 2$ \\
\hline
\end{tabular}

${ }^{1}$ oot - out of transect or opportunistic collection.

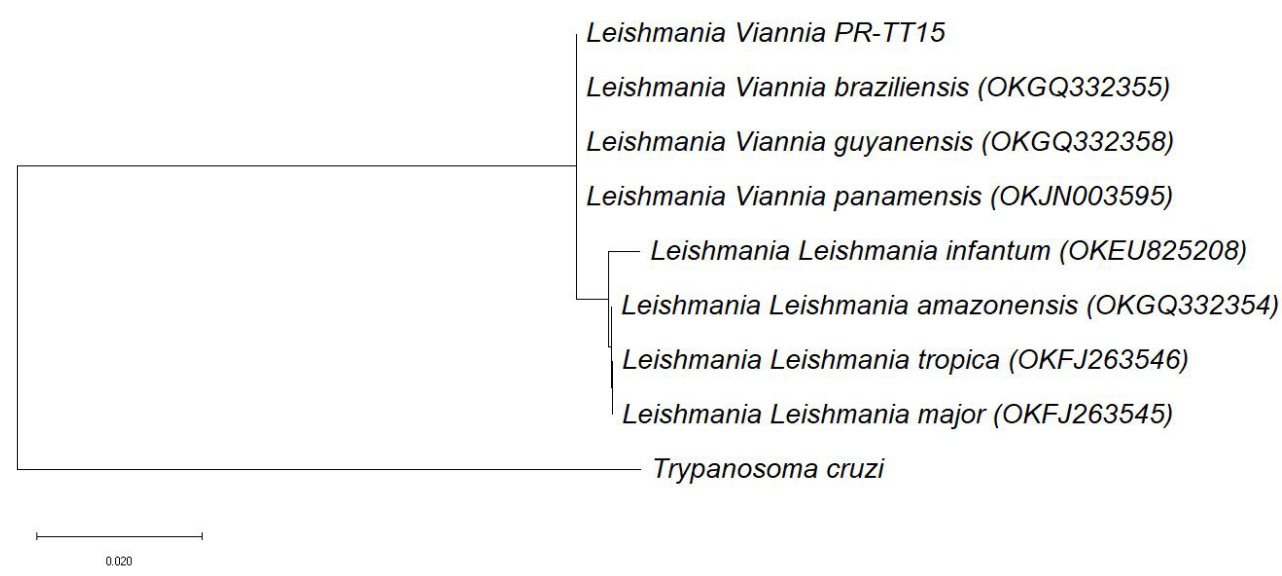

Figure 3. Phylogenetic reconstruction by the maximum-likelihood method with 1000 bootstraps, Tamura-Nei evolution model. Partial sequences of the minor subunit (18S) of ribosomal RNA from the Viannia subgenus (OKGQ332355, OKGQ332358, and OKJN003595) and from the Leishmania subgenus (OKEU825208, OKFJ263545, OKFJ263546, and OKGQ332354) were used in the alignment, and a Trypanosoma cruzi sequence was used as an outgroup.

\section{Discussion}

According to the Brazilian Center for Road Ecology Studies (CBEE), the Brazilian regions with the highest rates of trampling are the Southeast and South, and among states, Paraná occupies the second position and São Paulo the first (CBEE, 2019). Due to the threatened status of conservation and the current and consistent restrictions on the capture and euthanasia, and also to the difficulties in capturing some species (felids, anteater, primates), it might not be possible to obtain, more intensively way, samples of internal organs of these animals. Thus, it 
highlights that for the endangered species, such as the felids, sampling of trampling animals is essential to healthy and conservation studies. According to Richini-Pereira et al. (2014), carcasses of road-killed wild animals are a rich source of information and should be used for epidemiological studies on zoonoses and, in the specific case of leishmaniasis, help in the identification of hosts in different environments.

The assay to detect and determine the type of Leishmania must be sensitive enough to be used in clinical and epidemiological studies because it must be able to analyze a minimal number of parasites, even more when asymptomatic infections are being studied (Van der Auwera \& Dujardin, 2015). The present study is the first to evaluate a DNA detection technique for Leishmania spp. in various organs of different species of animals killed by trampling. Therefore, the PCR protocols were selected based on analytical sensitivity, but protocol specificity in these kinds of samples was not known.

The quality and quantity of the material used for DNA extraction is essential to rely on the results of molecular methods. The nature of the samples from the present study inspires care in this aspect based on postmortem autolysis. Although we used animals to run over less than 24 hours and that had a fresh condition, some organs are more susceptible to autolysis, such as the liver and bone marrow. In addition, intense bacterial multiplication, due to intestinal rupture or environmental temperature until the collected, leads to the sequestration and degradation of nucleic acids, which might result in false-negative results with PCR (Schrader et al., 2012). The best way to control this problem is to amplify mammalian constitutive gene and only use positive samples in the diagnosis of the pathogen in question, however, in this work, this step was not performed.

The results of DNA extraction yielded a satisfactory percentage of success when considering the liver (98.5\%) and skin (96.8\%), probably because of the size of the organ, allowing for the choice of a fragment of higher quality at the time of collection. In the specific case of bone marrow, it is known that autolysis occurs faster when compared to the other organs evaluated because of the low cellularity (Pineda Daboín et al., 2008). In the case of the spleen, the lesser success in the extraction (70.8\%) is probably based on the fact that the organ is very fibrous.

With respect to wild animals, the classification of visceral and cutaneous clinical forms caused by parasites of the genus, Leishmania, might not be applied (Roque \& Jansen, 2014) that is, all species of Leishmania might be found in any organ in these animals. For in vivo parasitological diagnosis of visceral leishmaniasis, the bone marrow together with the lymph node, spleen, and liver are the organs of choice (BRASIL, 2014) because of the higher number of parasites, such as lymphoid organs and tissues in which the Leishmania parasites multiply. The importance of looking for Leishmania DNA in the skin of these animals lies in looking for evidence of its role as a possible reservoir (Marcelino et al., 2011; Marquez et al., 2017).

The results obtained by PCR showed that the use of the LIT.SR and L5.8S, LinR4 and LinR17, and LinR19 primers, which amplify the ITS1 and kDNA genes, respectively, must be especially careful when DNA sequencing is not performed to confirm the result. After the unsatisfactory result of DNA sequencing, we submitted positive samples with a band size compatible with Leishmania spp. to PCR, raising the annealing temperature by 2 and $4^{\circ} \mathrm{C}$, and all samples had negative results. According to Van der Auwera \& Dujardin (2015), kDNA minicircles present high genetic variability within one unique strain, making it difficult to perform DNA sequencing. In addition, it is not a widely validated technique in clinical samples. Besides that, Aransay et al. (2000), also described unspecific weak bands around $600 \mathrm{bp}$ and $1000 \mathrm{bp}$. Primers LIT.SR and L5.8S, which amplify ITS1, were validated and tested in human and animal (domestic and wild) clinical samples presenting satisfactory results; however, only one strain of each investigated species was used, thereby overlooking possible intraspecies variation that could lead to erroneous results. It is important to emphasize that, in our study, we used a higher annealing temperature than that previously described $\left(53^{\circ} \mathrm{C}\right)$.

A complete review published in 2015 Van der Auwera \& Dujardin (2015) affirmed that HSP70 markers were the best for use in Leishmania species-typing globally. When comparing primers IRD and IRM in Primer BLAST, we found similarity between certain DNA sequences of Mus musculus (for example, NC_000068.7) and Rattus norvegicus (for example, NC_005108.4), with, until, two nucleotides of mismatch. When considering that all positive samples from the present study are from the Rodentia order, we suggest a non-specific amplification using the IRD and IRM primers in those animals. This finding emphasizes the necessity of validation in clinical samples from the species that are being studied. The primers designed by Van Eys et al. (1992), with a target that is the $18 \mathrm{~S}$ gene, have been shown to be the best option, specifically among the tested in the present study. For screening, when the goal is to detect DNA from parasites of the genus, Leishmania, one animal was confirmed to be infected with Leishmania. It is important to observe that the positivity occurred after a second DNA extraction as the first attempt was unsuccessful, and when the result of the first PCR reaction amplifying the $18 \mathrm{~S}$ gene was diluted in the proportion 
1:4 for the second reaction, proving the need for care, this gene, $18 \mathrm{~S}$, is not the most indicated for discrimination of the Leishmania species because it is a well-conserved region (Van der Auwera \& Dujardin, 2015).

Brazilian studies that aimed to investigate the presence of Leishmania DNA in the organs of wild animals that were killed were found in the literature. Soares (2013) worked with 49 animals from the state of Mato Grosso and 132 animals from Pará, Brazil. The authors used primers that amplify DNA from the 18S gene from the Trypanosomatidae family of parasites (Maia da Silva et al., 2004) and did not identify any positive animals in the spleen or lung, even if the states that they worked in are known to be endemic for leishmaniasis (706 and 609 primers and AT of $60^{\circ} \mathrm{C}$ ). Alves-Palmeira (2018) evaluated 297 animals collected on highways in the state of Santa Catarina and did not find any positive animals for Leishmania spp. using spleen, liver, heart, lung, and skin. The amplified gene was ITS1 (LTSR and L5.8S primers and AT of $53^{\circ} \mathrm{C}$ ). Richini-Pereira et al. (2014) conducted a study using 70 animals from the state of São Paulo, and DNA from parasites of the genus, Leishmania, was detected in $22.85 \%(16 / 70)$ of the animals tested (C. aperea, Cerdocyon thous, Dasypus septemcinctus, D. albiventris, H. hydrochaeris, Myrmecophaga tridactyla, Procyon cancrivorus, Scutiger spinosus, and T. tetradactyla). The positive organs were lung, heart, liver, spleen, kidney, and lymph node. All positives were confirmed by DNA sequencing as Leishmania spp., and $L$. (L.) infantum DNA was confirmed in the mesenteric lymph node of a $C$. thous. kDNA was the target of the amplification (LinR4 and Lin19 primers, as well as AT at $63^{\circ} \mathrm{C}$ ).

In free living T. tetradactyla species, DNA from Leishmania (Viannia) guyanensis (Lainson et al., 1981) and L. (L.) infantum (de Araújo et al., 2013) were detected in the state of Pará, Brazil, and L. (L.) amazonensis in Ecuador (Mimori et al., 1989). The role of anteaters in the epidemiology of leishmaniasis is not well-known, and presently, they are considered only hosts (Roque \& Jansen, 2014). This animal species has behavioral and biological specificities that make it especially susceptible to leishmaniasis. Anteaters are relatively large and slow, and they spend much time climbing trees in close intimate contact with phlebotomines that inhabit tree trunks, such as Lutzomyia umbratilis and Lutzomyia whitmani (Lainson et al., 1981); in addition, they present a deficient cellular immune response (Bagagli \& Bosco, 2008), which is the most important in case of infection by intracellular parasites. These characteristics make them suitable models for studying pathogen-host interactions (Richini-Pereira et al., 2014).

The parasite identified in the present study is of the subgenus Viannia, which occurs in the New World and contemplates species that cause American cutaneous leishmaniasis (ACL) in Brazil (Brasil, 2017). Small wild mammals are probably the primary reservoirs of ACL in Brazil (Dantas-Torres et al., 2010); according to Roque \& Jansen (2014), several species of wild animals have been reported as hosts of ACL parasites in Brazil, such as marsupials, armadillos, anteaters, wild felines, primates, and bats.

Regarding the evaluation of an active and early surveillance methodology of leishmaniasis by molecular detection in road-killed wild fauna, based in our results, we feel free to make several suggestions: (i) The means of obtaining samples-the union of several strategies, like traversing pre-established transects, co-participation with environmental and road police, and co-participation with concessionaires on toll roads; (ii) procedures with tissue samples-the shortest possible time between animal death and tissue freezing, careful collection of areas with less autolysis when possible, concentration control after DNA extraction, re-extraction in cases of failure; (iii) organs of choice-even if more studies must be carried out to be able to state with certainty, what is known so far is that lymph nodes must be on the list. In addition, the use of a larger number of different tissues may increase the sensitivity of the diagnosis; and (iv) the PCR protocol-nPCR using primers 221 and 332 in the first step and 222 and 333 in the second step that amplify 18 gene.

\section{Conclusion}

The present study is the first to evaluate a DNA detection methodology for Leishmania spp. in various organs of different species of road-killed animals from Paraná state. We suggest using the methodology evaluated in the present study in the active and early surveillance of visceral leishmaniasis in a non-endemic area as it was able to detect the presence of Leishmania spp. in organs of road-killed wild animals. No DNA of L. (L.) infantum was detected in any of the organs of the evaluated animals. The active surveillance in the North of Paraná must be constant as the risk remains real because it is close to endemic municipalities of the West of São Paulo.

\section{Acknowledgements}

We thank CAPES for the PhD scholarship and CNPq for the productivity scholarship. We are grateful to Professor Selwyn Arlington Headley and pathological anatomy residents for helping with autopsies. We thank to the managers of the co-participating regional health of the state of Parana (15th, 16th, 17th and 18th) and the commanders of the 2nd Company of Environmental Police and 2nd Road Police Company. 


\section{References}

Alvar J, Vélez ID, Bern C, Herrero M, Desjeux P, Cano J, et al. Leishmaniasis Worldwide and Global Estimates of its Incidence. PLoS One 2012; 7(5): e35671. http://dx.doi.org/10.1371/journal.pone.0035671. PMid:22693548.

Alves-Palmeira ARDO. Análise espacial e detecção molecular de Leishmania spp. e Trypanosoma spp. em animais silvestres mortos por atropelamento no estado de Santa Catarina [dissertação]. Florianópolis: Universidade de Santa Catarina; 2018.

Aransay AM, Scoulica E, Tselentis Y. Detection and identification of Leishmania DNA within naturally infected sand flies by seminested PCR on minicircle kinetoplastic DNA. App/ Environ Microbio/ 2000; 66(5): 1933-1938. http://dx.doi.org/10.1128/ AEM.66.5.1933-1938.2000. PMid:10788363.

Bagagli E, Bosco SMG. Armadillos and dimorphic pathogenic fungi: ecological and evolutionary aspects. In: Viscaino SF, Loughry WJ. The biology of the Xenarthra. Florida: University Press of Florida; 2008. p. 103-110.

Brasil. Ministério da Saúde. Secretaria de Vigilância em Saúde. Departamento de Vigilância Epidemiológia. Manual de vigilância e controle de Leishmaniose visceral [online]. Brasília: Ministério da Saúde; 2014 [cited 2020 Nov 28]. Available from: http://www. saude.ba.gov.br/wp-content/uploads/2019/05/2014-Manual-de-vigil\%C3\%A2ncia-e-controle-da-leishmaniose-visceral.pdf

Brasil. Ministério da Saúde. Secretaria de Vigilância em Saúde. Departamento de Vigilância de Doenças Transmissíveis. Manual de vigilância e controle da Leishmaniose Tegumentar Americana [online]. Brasília: Ministério da Saúde; 2017 [cited 2020 Nov 28]. Available from: http://bvsms.saude.gov.br/bvs/publicacoes/manual_vigilancia_leishmaniose_tegumentar.pdf

Caldart ET, Camilo CP, Moreira JR, Matos AMRN, Ferreira FP, Paschoal ATP, et al. Canine visceral leishmaniasis in Londrina, Paraná - Investigation and case report. Semina: Ciênc Agrár 2018; 39(3): 1371-1375. http://dx.doi.org/10.5433/1679-0359.2018v39n3p1371.

Caldart ET, Freire RL, Ferreira FP, Ruffolo BB, Sbeghen MR, Mareze M, et al. Leishmania in synanthropic rodents (Rattus rattus): New evidence for the urbanization of Leishmania (Leishmania) amazonensis. Rev Bras Parasitol Vet 2017; 26(1): 17-27. http://dx.doi. org/10.1590/s1984-29612017001. PMid:28177041.

Centro Brasileiro de Estudos em Ecologia de Estradas - CBEE. Atropelamentos de fauna selvagem [online]. 2019 [cited 2020 Nov 28]. Available from: http://cbee.ufla.br/portal/atropelometro/

D'Andrea LA, Fonseca ES, Prestes-Carneiro LE, Guimarães RB, Yamashita RC, Soares CN, et al. The shadows of a ghost: a survey of canine leishmaniasis in Presidente Prudente and its spatial dispersion in the western region of São Paulo state, an emerging focus of visceral leishmaniasis in Brazil. BMC Vet Res 2015; 11(1): 273. http://dx.doi.org/10.1186/s12917-015-0583-6. PMid:26503368.

Da Silva FM, Noyes H, Campaner M, Junqueira AC, Coura JR, Añez N, et al. et al. Phylogeny, taxonomy and grouping of Trypanosoma rangeli isolates from man, triatomines and sylvatic mammals from widespread geographical origin based on SSU and ITS ribosomal sequences. Parasitology 2004; 129(Pt 5): 549-561. http://dx.doi.org/10.1017/S0031182004005931. PMid:15552400.

Dantas-Torres F, de Paiva-Cavalcanti M, Figueredo LA, Melo MF, da Silva FJ, da Silva AL, et al. Cutaneous and visceral leishmaniosis in dogs from a rural community northeastern Brazil. Vet Parasitol 2010; 170(3-4): 313-317. http://dx.doi.org/10.1016/j. vetpar.2010.02.019. PMid:20227186.

de Araújo VA, Boité MC, Cupolillo E, Jansen AM, Roque ALR. Mixed infection in the anteater Tamandua tetradactyla (Mammalia: Pilosa) from Pará State, Brazil: Trypanosoma cruzi, T. rangeli and Leishmania infantum. Parasitology 2013; 140(4): 455-460. http:// dx.doi.org/10.1017/S0031182012001886. PMid:23253893.

Dias RCF, Pasquali AKS, Thomaz-Soccol V, Pozzolo EM, Chiyo L, Alban SM, et al. Autochthonous canine visceral leishmaniasis cases occur in Paraná state since 2012: isolation and identification of Leishmania infantum. Rev Bras Parasitol Vet 2019; 29(1): e009819. http://dx.doi.org/10.1590/s1984-29612019083. PMid:31691734.

Dujardin JC, Campino L, Cañavate C, Dedet JP, Gradoni L, Soteriadou K, et al. Spread of vector-borne diseases and neglect of leishmaniasis, Europe. Emerg Infect Dis 2008; 14(7): 1013-1018. http://dx.doi.org/10.3201/eid1407.071589. PMid:18598618.

Gramiccia M. Recent advances in leishmaniosis in pet animals: epidemiology, diagnostics and anti-vectorial prophylaxis. Vet Parasitol 2011; 181(1): 23-30. http://dx.doi.org/10.1016/j.vetpar.2011.04.019. PMid:21570192.

International Union for Conservation of Nature - IUCN. [online]. 2019 [cited 2020 Nov 28]. Available from: https://www.iucnredlist. org/

Lainson R, Shaw JJ, Ready PD, Miles MA, Póvoa M. Leishmaniasis in Brazil: XVI: Isolation and Identification of Leishmania species from sandflies, wild mammals and man in north Pará state, with particular reference to L. braziliensis guyanensis causative agent of "pian-bois". Trans R Soc Trop Med Hyg 1981; 75(4): 530-536. http://dx.doi.org/10.1016/0035-9203(81)90192-9. PMid:7324128.

Marcelino AP, Ferreira EC, Avendanha JS, Costa CF, Chiarelli G, Almeida G, et al. Molecular detection of Leishmania braziliensis in Rattus norvegicusin an area endemic for cutaneous leishmaniasis in Brazil. Vet Parasitol 2011; 183(1-2): 54-58. http://dx.doi. org/10.1016/j.vetpar.2011.06.019. PMid:21767914.

Marquez ES, de Castro EA, Nabut LB, da Costa-Ribeiro MCV, Dela Coletta Troiano Araújo L, Poubel SB, et al. Cutaneous leishmaniosis in naturally infected dogs in Paraná, Brazil, and the epidemiological implications of Leishmania (Viannia) braziliensis detection in internal organs and intact skin. Vet Parasito/ 2017; 243: 219-225. http://dx.doi.org/10.1016/j.vetpar.2017.07.003. PMid:28807297. 
McCluskey BJ, Burgess B, Glover J, Kinde H, Hietala S. Use of sentinel chickens to evaluate the effectiveness of cleaning and disinfection procedures in noncommercial poultry operations infected with exotic Newcastle disease virus. J Vet Diagn Invest 2006; 18(3): 296-299. http://dx.doi.org/10.1177/104063870601800313. PMid:16789722.

Mimori T, Grimaldi G Jr, Kreutzer RD, Gomez EA, McMahon-Pratt D, Tesh RB, et al. Identification, using isoenzyme electrophoresis and monoclonal antibodies, of Leishmania isolated from humans and wild animals of Ecuador. Am J Trop Med Hyg 1989; 40(2): 154-158. http://dx.doi.org/10.4269/ajtmh.1989.40.154. PMid:2919726.

Neitzke-Abreu HC, Santos DR, Silva AM, Reinhold-Castro KR, Silveira TGV, Lonardoni MVC, et al. Alteration in frequency of sand flies in domiciles after changes in the peridomicile area, State of Paraná, Brazil. J Vector Ecol 2012; 37(2): 466-470. http://dx.doi. org/10.1111/j.1948-7134.2012.00253.x. PMid:23181874.

Pineda Daboín KMP, García GR, García MIR, Uribe AR. Biopsia de medula óssea: utilidade y limitaciones. Patol Ver Latinoam 2008; 46(3): 237-247.

Pugliares KR, Bogomolni AL, Touhey KM, Herzig SM, Harry CT, Moore MJ. Marine mammal necropsy: an introductory guide for stranding responders and field biologists. Massachusetts: Woods Hole Oceanographic Institution; 2007. http://dx.doi.org/10.1575/1912/1823.

Reinhold-Castro KR, Fenelon VC, Rossi RM, Brito JEC, Freitas JS, Teodoro U. Impact of control measures and dynamics of sand flies in southern Brazil. J Vector Ecol 2013; 38(1): 63-68. http://dx.doi.org/10.1111/j.1948-7134.2013.12009.x. PMid:23701608.

Requena JM, Chicharro C, García L, Parrado R, Puerta CJ, Cañavate C. Sequence analysis of the 3'-untranslated region of HSP70 (type I) genes in the genus Leishmania: its usefulness as a molecular marker for species identification. Parasit Vectors 2012; 5(1): 87. http://dx.doi.org/10.1186/1756-3305-5-87. PMid:22541251.

Richini-Pereira VB, Marson PM, Hayasaka EY, Victoria C, da Silva RC, Langoni H. Molecular detection of Leishmania spp. in roadkilled wild mammals in the Central Western area of the State of São Paulo, Brazil. J Venom Anim Toxins Incl Trop Dis 2014; 20(1): 27. http://dx.doi.org/10.1186/1678-9199-20-27. PMid:24963288.

Roque ALR, Jansen AM. Wild and synanthropic reservoirs of Leishmania species in Americas. Int J Parasitol Parasites Wildl 2014; 3(3): 251-262. http://dx.doi.org/10.1016/j.ijppaw.2014.08.004. PMid:25426421.

Santos DR, Ferreira AC, Bisetto A Jr. The first record of Lutzomyia longipalpis (Lutz \& Neiva, 1912) (Diptera: Psychodidae: Phlebotominae) in the State of Paraná, Brazil. Rev Soc Bras Med Trop 2012; 45(5): 643-645. http://dx.doi.org/10.1590/S003786822012000500019 . PMid:23152351.

Schönian G, Nasereddin A, Dinse N, Schweynoch C, Schallig HD, Presber W, et al. PCR diagnosis and characterization of Leishmania in local and imported clinical samples. Diagn Microbiol Infect Dis 2003; 47(1): 349-358. http://dx.doi.org/10.1016/ S0732-8893(03)00093-2. PMid:12967749.

Schrader C, Schielke A, Ellerbroek L, Johne R. PCR inhibitors - occurrence, properties and removal. J App/ Microbiol 2012; 113(5): 1014-1026. http://dx.doi.org/10.1111/j.1365-2672.2012.05384.x. PMid:22747964.

Silva AM, Camargo NJ, Santos DR, Massafera R, Ferreira AC, Postai C, et al. Diversidade, distribuição e abundância de flebotomíneos (Diptera: Psychodidae) no Paraná. Neotrop Entomo/ 2008; 37(2): 209-225. http://dx.doi.org/10.1590/S1519-566X2008000200017. PMid:18506303.

Silva LA, de Sousa CS, da Graça GC, Porrozzi R, Cupolillo E. Sequence analysis and PCR-RFLP profiling of the $h s p 70$ gene as a valuable tool for identifying Leishmania species associated with human leishmaniasis in Brazil. Infect Genet Evol 2010; 10(1): 7783. http://dx.doi.org/10.1016/j.meegid.2009.11.001. PMid:19913112.

Silva NMMG, de Melo SCCS, Massafera R, Rossi RM, Silveira TGV, Teodoro U. Dispersal and Memory of Sand Flies in an Endemic Area of Cutaneous Leishmaniasis, Southern Brazil. J Med Entomol 2013; 50(5): 986-993. http://dx.doi.org/10.1603/ME12065. PMid:24180102.

Sistema de Informação de Agravos de Notificação - SINAN. [online]. 2020 [cited 2020 Nov 28]. Available from: http://www2. datasus.gov.br/DATASUS/index.php?area=0203\&id=29892192\&VObj

Soares HS. Pesquisa de carrapatos, agentes transmitidos por carrapatos e tripanossomatídeos em animais silvestres dos Estados do Mato Grosso e Pará [dissertação]. Cuiabá: Universidade do Mato Grosso; 2013.

Trench FJP, Ritt AG, Gewehr TA, Leandro AS, Chiyo L, RittGewehr M, et al. First Report of Autochthonous Visceral Leishmaniosis in humans in Foz do Iguaçu, Paraná State, Southern Brazil. Ann Clin Cytol Pathol 2016; 2(6): 1041.

Van der Auwera G, Dujardin JC. Species typing in dermal leishmaniasis. Clin Microbio/ Rev 2015; 28(2): 265-294. http://dx.doi. org/10.1128/CMR.00104-14. PMid:25672782.

Van Eys GJJM, Schoone GJ, Kroon NCM, Ebeling SB. Sequence analysis of small subunit ribosomal RNA genes and its use for detection and identification of Leishmania parasites. Mol Biochem Parasitol 1992; 51(1): 133-142. http://dx.doi.org/10.1016/01666851(92)90208-2. PMid:1565128. 
Visceral leishmaniasis surveillance

\section{Supplementary Material}

File 1. Sequence obtained in the present study (Leishmania Viannia PR-TT15) in the FASTA format. 